\title{
Construindo uma explicação da censura em "Mas apenas e antigamente guirlandas sobre o poço", de Caio Fernando Abreu
}

\author{
Constructing an explanation of censorship in \\ "But only once and garlands over the pit", by Caio Fernando Abreu
}

\author{
DEIVIS JHONES GARLET \\ ROSANI KETZER UMBACH \\ Universidade Federal de Santa Maria - Santa Maria - Rio Grande do Sul - Brasil
}

DV

\begin{abstract}
Resumo: Considerando a censura como elemento integrante da superestrutura jurídica e política da Ditadura Civil-militar brasileira, propomos uma análise do conto "Mas apenas e antigamente guirlandas sobre o poço", de Caio Fernando Abreu, o qual foi censurado em 1975. O objetivo consiste em construir, com o recurso de conceitos do Círculo de Bakhtin, como os de reflexo e de refração do fazer artístico e de meio ideológico, juntamente à legislação sobre censura da época, uma explicação dos motivos que podem ter levado ao corte da narrativa e, assim, uma compreensão do pensamento político do autor como um contraponto simbólico ao autoritarismo militar. Desse modo, nosso estudo situa-se no âmbito dos estudos literários de crítica social e de literatura comparada.
\end{abstract}

Palavras-chave: Literatura; Ditadura Civil-militar; Censura; Política

\begin{abstract}
Considering censorship as part of the Civil-Military Dictatorship Brazilian political element of the legal superstructure and propose an analysis of the short story "But only once and garlands over the pit," by Caio Fernando Abreu, who was censured in 1975. The goal is to building, with the feature of the Bakhtin Circle concepts, such as reflection and refraction of art making and ideological means, coupled to the legislation on censorship of the time, an explanation of the reasons that may have led to the cutting of the narrative and thus an understanding of the political thought of the author as a symbolic counterpoint to the military authoritarianism. Thus, our study lies in the scope of literary studies of social criticism and comparative literature.
\end{abstract}

Keywords: Literature; Civil-Military Dictatorship; Censorship; Policy

O período compreendido entre os anos de 1964 e 1985, no Brasil, caracterizou-se pela vigência da Ditadura Civil-militar, a qual colocou em prática uma política de repressão aos supostos subversivos, efetuando prisões, cassação de mandatos políticos, afastamento de professores marxistas, censura e toda ordem de violação aos direitos e garantias constitucionais dos cidadãos. Evidentemente, também houve inúmeros focos de oposição, a exemplo da guerrilha, de greves, de passeatas estudantis, de movimentos contraculturais e de obras artísticas, como as ligadas à literatura, que instalaram específico posicionamento axiológico contestador do status quo. A produção de Caio Fernando Abreu, embora reconhecidamente marcada pelo intimismo e pela subjetividade, dialoga com esse contexto, construindo um contraponto simbólico ao pensamento político dominante, de matiz autoritário, conservador e cerceador das liberdades individuais e coletivas. Segundo Jaime Ginzburg (1996), a obra de Caio Fernando Abreu ainda necessita de uma análise mais detida em um de seus elementos mais expoentes, ou seja, a política.

Nossa proposta de análise consiste em efetuar um estudo analítico-hermenêutico do conto "Mas apenas e antigamente guirlandas sobre o poço", publicado em Ovelhas negras, em 1995, mas que fazia parte da coletânea O ovo apunhalado, de 1975, sendo, na época, censurado, com o objetivo de elucidarmos os motivos que podem ter levado ao corte da narrativa. Assim, para lograr êxito 
em nossa proposta, recorreremos às leis sobre censura da Ditadura Civil-militar, entendendo a censura como uma ação que denota a essência da política do governo militar, ou seja, o autoritarismo, em comparação com o texto literário.

Assim, a investigação consiste em analisar o objeto nos parâmetros da crítica social, em especial com os conceitos de meio ideológico, de reflexo e de refração pertinentes ao Círculo de Bakhtin, articulando o estudo da especificidade da literatura com teorias e conceitos inerentes à história e à ciência política, de modo interdisciplinar e no âmbito da literatura comparada. Considerando a obra artística como um objeto-signo portador de carga axiológica, potencialmente ideológica, que interage reciprocamente com o contexto de produção, entendemos que o escritor, imerso em determinado meio ideológico, opera, seletivamente, no ato estético, um reflexo e uma refração de reflexos e refrações que o circundam, transformando-os e criando a realidade da ficção, em conexão com a realidade concreta da vida dos homens. Essa reflexão não nos é original, mas apreendida em Candido ${ }^{1}$, Bakhtin² e Medviédev. Dada a importância do meio ideológico, recorremos ao conceito:

O homem social está rodeado de fenômenos ideológicos, de "objetos-signo" dos mais diversos tipos e categorias: de palavras realizadas nas suas mais diversas formas, pronunciadas, escritas e outras; de afirmações científicas; de símbolos crenças religiosas; de obras de arte, e assim por diante. Tudo isso em seu conjunto constitui o meio ideológico que envolve o homem por todos os lados em um círculo denso. Precisamente nesse meio vive e se desenvolve sua consciência. A consciência humana não toca a existência diretamente, mas através do mundo ideológico que a rodeia. (MEDVIÉDEV, 2012:56)

Trabalhando, pois, com os produtos ideológicos que o cercam - extraestéticos -, o escritor opera, no ato estético, um reflexo e uma refração da realidade concreta, ou seja, os elementos do contexto material são transmutados para a realidade da obra artística com uma independência de funcionamento, ora confirmando a realidade extraestética, ora refutando-a.

Escusando-nos de uma exaustiva caracterização do meio ideológico que circundava Caio Fernando Abreu, nos daremos por satisfeitos, neste momento, em afirmar que consistia na Ditadura Civil-militar, com a estrutura econômica capitalista associada e dependente do capital estrangeiro e as superestruturas pertinentes, estas como áreas de criação ideológica, como a jurídica-política, a moral, a religiosa, entre outras. Na sequência de análise do conto, elementos extraestéticos constituintes do meio ideológico e que são transfigurados para o interior da narrativa, tornando-se estéticos, serão apresentados de maneira mais adequada.

O conto "Mas apenas e antigamente guirlandas sobre o poço" é precedido por uma epígrafe, mais exatamente um verso do poeta Allen Ginsberg, a qual nos permite entrever uma possível influência, em termos de ideais e de transtextualidade, definida por Genette (2010:11) como "tudo que o coloca [o texto] em relação, manifesta ou secreta, com outros textos.", sobre a narrativa de Caio Fernando Abreu, auxiliando então para uma compreensão do conto em análise.

O verso, citado pelo escritor gaúcho em língua inglesa, pode ser assim traduzido, livremente e assumindose os riscos de tal tradução amadora, uma vez que não encontramos sua tradução para o português: "Sim eu sou aquela alma verme sob o inferno dos cavalos demoníacos." ${ }^{3}$ Como tentaremos evidenciar, estabelece-se uma relação transtextual, principalmente ao compreendermos que o conto de Caio Fernando Abreu expressa o tormento de uma alma interior corrompida, sombria e violenta, em uma correlação com a 'alma verme' da citação.

Em relação aos ideais e o modo de vida de Allen Ginsberg, de forma bastante genérica, devemos informar que foi um poeta estadunidense que alcançou notoriedade com a publicação do poema "Uivo", em 1956, o qual gerou um processo jurídico contra o autor alegando-se a imoralidade obscena e pornográfica do poema. "Uivo", por sua vez, também estabelece uma relação transtextual com a narrativa em causa, sobremodo porque o narrador-personagem de "Mas apenas e antigamente guirlandas sobre o poço" afirma sua ferocidade de lobo, e assim percebemos um nível de transtextualidade ao considerarmos a similaridade aproximativa entre 'uivo' (um som agudo de alguns animais selvagens) e 'lobo' (um animal selvagem que uiva), mesmo que seja em um nível de superfície, já que uma análise da poesia de Allen Ginzberg excederia nossos limites de trabalho.

Além disso, o autor de "Uivo" foi um ícone da denominada Geração Beat, na década de 1950, a qual era formada por um grupo de escritores, entre eles Jack Kerouac, que se opunha à ordem vigente, tanto em termos políticos e ideológicos, quanto literários. De um modo sintético, podemos aventar que a Geração Beat combatia as convenções sociais, a violência em todas as suas formas e defendia a liberdade individual, passando por experiências místicas, uso de drogas ilícitas, liberação sexual e culminando na liberdade de criação literária, com

\footnotetext{
CANDIDO, Antonio. Literatura e Sociedade: Estudos de Teoria e História Literária. 11. ed. Rio de Janeiro: Ouro sobre Azul, 2010.

2 BAKHTIN, Mikhail; VOLOCHÍNOV. Marxismo e filosofia da linguagem: problemas fundamentais do método sociológico da linguagem. São Paulo: Hucitec, 2012.

3 Em inglês: "Yes I am that worm soul under the hell of the daemon horses
} - Allen Ginsberg". 
a recusa do formalismo academicista e a valorização de construções artísticas com expressão formal do fluxo de consciência carregado de simbolismo, por vezes caótico e confuso, mas resultante em uma linguagem autônoma, propulsora de estados sensoriais inefáveis.

A Geração Beat, e particularmente Allen Ginsberg, é considerada precursora do movimento hippie, seja em suas propostas, seja no modo de ser e de agir empíricos. Nesse sentido há uma aproximação com Caio Fernando Abreu, pois este viveu como hippie (por um curto período) e propagou muitos dos postulados hippies, como o ideal maior de liberdade. Segundo Dip (2009:140), "Em 1971 (...) Caio volta uma vez mais para o Rio de Janeiro. Vai morar em Botafogo, numa comunidade hippie. A contracultura estava no auge e ele, que colecionava atitudes revolucionárias, deixa crescer ainda mais o cabelo, usa túnicas indianas, experimenta mescalina, chá de cogumelos, maconha...”. Esse arquétipo do hippie encontra intensa semelhança com Allen Ginsberg, o qual também possuía cabelos longos, barba e usava túnicas. Em termos de arquétipo, o poeta estadunidense e Caio Fernando Abreu possuem notável semelhança, embora as influências sobre o escritor brasileiro também devam ser percebidas na realidade material do Brasil das décadas de 1960 e 1970. Outro traço aproximador entre os dois escritores reside na opção homoerótica em uma época de recrudescido preconceito (ainda não eliminado do imaginário e da práxis social completamente), na defesa da liberdade, na expressão dos conflitos do eu interior e na linguagem simbólica empregada na arquitetura estética, como no conto em análise.

A Geração Beat e o movimento hippie, entretanto, são constituintes de um movimento mais abrangente, denominado contracultura, estabelecendo uma ligação entre os princípios contraculturais e a obra de Caio Fernando Abreu.

Em síntese, a contracultura caracteriza-se por sustentar o primado da individualidade e da liberdade em detrimento de imposições normativas do Estado e da sociedade, como a moral, afirmando o ideal de transformação do indivíduo, interiormente, e da sociedade, coletivamente. Também concede apreço à alteridade, à pluralidade cultural, à diversidade e se opõe a qualquer forma de cerceamento autoritário. No plano artístico, promove uma ação de ruptura e inovação em relação ao considerado tradicional. Uma definição apropriada de contracultura pode ser assim enunciada:

Nossa definição é a de que a essência da contracultura como um fenômeno histórico perene é caracterizado pela afirmação do poder individual de criar sua própria vida, mais do que aceitar os ditames das autoridades sociais e convenções circundantes, sejam elas dominantes ou subculturais. (GOFFMAN; JOY, 2007:49)
Assim, podemos considerar que, efetuando um exercício de comparação, os contos de O Ovo apunhalado integram-se harmoniosamente com os princípios da contracultura. Em narrativas como "A margarida enlatada", "Iniciação", "O afogado", "Eles", "Ascensão e queda de Robhéa, manequim \& robô", "Triângulo em cravo e flauta doce" e, objeto de nossa análise, "Mas apenas e antigamente guirlandas sobre o poço" a liberdade é confrontada por excessos repressivos de teor autoritário, através do princípio de construção artístico dialógico e contendo um posicionamento axiológico de valoração da liberdade, da individualidade, da mudança, do inconformismo, da não aceitação das imposições normativas de toda ordem, tidas como nefastas no plano narrativo e também em retorno ao contexto de produção, pondo em conexão literatura e contexto material.

"Mas apenas e antigamente guirlandas sobre o poço" inclui-se nessa conjuntura ao iniciar com uma referência ao poeta Allen Guinsberg, e prossegue em sua construção formal e temática operando um reflexo e uma refração desse meio ideológico contracultural e a repressão social no eu interior dos indivíduos.

O conto também é precedido por um comentário explicativo do escritor, informando-nos a gênese do mesmo (desconhecida) e a censura sofrida:

É um dos contos mais estranhos que escrevi, em 1970 ou 1971, mas não lembro onde ou por quê. Sua gênese é mistério absoluto para mim. Publicado uma única vez no "Caderno de Sábado" do Correio do Povo, com direito a belíssima ilustração de Nelson Boeira Faedrich, foi depois incluído em $\mathrm{O}$ ovo apunhalado e retirado do livro pela censura interna do IEL (leia-se Paulo Amorim). Tem alguns vanguardismos gratuitos e pirotecnias de pontuação (não há nenhuma vírgula, por exemplo) mas de alguma forma irracional me horroriza tanto quanto fascina, talvez justamente por não saber de onde veio tanta violência e sombra. (ABREU, 2005:221, grifos do autor)

Com o aval das palavras do escritor, temos a constatação objetiva da censura efetuada pelo Instituto Estadual do Livro (IEL). Além disso, nos fornece elementos para uma explicação do conto nos parâmetros da contracultura, como a recusa do formalismo tradicional denotada na expressão 'vanguardismos' e 'pirotecnias de pontuação', ou mesmo os vocábulos 'estranhos' e 'mistério' e a declaração de 'não saber de onde veio tanta violência e sombra', articuladores de uma significação obscura. De fato, a narrativa apresenta uma linguagem simbólica extremamente enigmática, por vezes incompreensível, instauradora de uma ampla polissemia.

O conto está incluído em Ovelhas Negras, na segunda de três partes, sob o título chinês "K'na", o 
qual, de acordo com Porto (2013), simboliza o elemento natural água, os perigos e a necessidade de superá-los. Ainda segundo Porto (2013:248), os oito contos da seção "K'na" - incluindo "Mas apenas e antigamente guirlandas sobre o poço" - "... indicam um tom sombrio e nebuloso das histórias, que se mostram também embaçadas aos olhos do leitor, visto as imensas imagens simbólicas da desesperança e da dor." Portanto, cremos na plausibilidade de caracterizar, a priori, a narrativa como enigmática, embebida por um simbolismo que sugere múltiplas possíveis leituras. Em face disso, nossa proposta de análise consiste em uma tentativa de leitura plausível em um leque de possibilidades, com o intuito de explicar os motivos que levaram o conto a ter sua publicação proibida em 1975.

O foco narrativo concentra-se na voz de um narradorpersonagem que relembra a ida até um apartamento, conduzido por uma mulher, para ser apresentado a outro homem. O narrador-personagem organiza seu relato em três etapas: um 'antes', um 'durante' e um 'depois'.

No 'antes', descreve a chegada ao apartamento, junto à mulher, passando por um elevador, por um corredor cinzento, de ladrilhos escuros e uma luz amarelada, até chegarem à porta e tocarem a campainha. Nesse momento, o narrador-personagem parece iniciar o exame de seu eu interior, tom que se estenderá até o final. Ao ouvir a campainha, em um diálogo interior, afirma que “... estava imerso numa espécie de escolha assim como um lago escuro de fundo e superfície iguais onde nunca outra vez as pedras ou as folhas caídas no outono formariam círculos concêntricos." (ABREU, 2005:222).

A simbologia ${ }^{4}$ do lago, embora com variadas significações, pode ser associada ao eu interior, ao conhecimento de si. No caso em análise, a indicar pelo adjetivo 'escuro' e a alusão à igualdade entre fundo e superfície, somada ao fato de pedras ou folhas não mais movimentarem a água, infere-se uma paralisia, um caráter estático de um eu interior submerso na escuridão que não poderá ser alterada. Esse traço estático, portanto imóvel, sugere a não aceitação do movimento, da mudança, da abertura ao desconhecido, corporificado no homem que a mulher deseja lhe apresentar. Esse eu interior marcado pela imobilidade é ratificado no momento em que, uma vez que parece não haver ninguém no apartamento, dispõe-se a ir embora, sem o encontro se realizar, e afirma que "Não lamentei. Sei que não lamentei porque inesperava que alguém ou alguma coisa voltasse a perfurar o endurecido

\footnotetext{
4 Todas as significações simbólicas apresentadas a partir deste ponto são tomadas de empréstimo das obras CHEVALIER, Jean; GHEERBRANT, Alain. Dicionário de símbolos: mitos, sonhos, costumes, gestos, formas, figuras, cores, números. Tradução de Vera da Costa e Silva et al. 26.ed. Rio de Janeiro: José Olympio, 2012. BIEDERMANN, Hans. Dicionário ilustrado de símbolos. Tradução Glória Pachoal de de Camargo. 10. ed. São Paulo: Melhoramentos, 1999.
}

que fora se sedimentando ano após ano no de dentro do meu eu por dentro." (ABREU, 2005:222-223). Ou seja, no fundo de seu lago, de seu eu interior, como a própria linguagem da narrativa sugere, o narrador-personagem não anseia pelo encontro, posto que avesso a mudanças, ao desconhecido, e está petrificado - imóvel - por dentro.

Essas primeiras impressões permitem que situemos o conto no âmbito de uma perspectiva intimista, na qual a análise do eu interior e o tom introspectivo prevalecem. Desse modo, a narrativa circunscreve-se na denominada vertente existencial-intimista, taxonomia proposta e conceituada por Bittencourt (1999). Segundo a pesquisadora, os contos que se incluem nessa categoria "São narrativas que enfatizam a perspectiva subjetiva, desnudando os mistérios que se escondem no interior do ser humano, revelando seus desejos ocultos ou até mesmo percorrendo os subterrâneos nebulosos, às vezes enigmáticos e perturbados, da sua mente." (BITTENCOURT, 1999:92). Esse nos parece constituir o epicentro da narrativa em análise, ou seja, o desvelamento de um eu interior enigmático e nebuloso, sob acentos de subjetividade.

O conto prossegue com o 'durante', momento em que o homem abre a porta do apartamento e ocorre o encontro, seguindo-se olhares, toques físicos, um conflito interior do narrador-personagem e um derradeiro diálogo entre os dois. $\mathrm{O}$ eu interior vai se revelando tensamente, confusamente, por meio de uma linguagem simbólica enigmática e repleta de possíveis significações.

Logo ao ver o homem do apartamento, o narradorpersonagem percebe um sentimento selvagem emergindo do seu âmago: "E foi então que o lobo veio à tona. Encolheu-se encolhendo as unhas feito gavinha de planta carnívora aconchegada à própria ferocidade." (ABREU, 2005:223). Petrificado por dentro, impossibilitado de reagir com acolhimento, posto que endurecido, sua reação anuncia violência na figura do lobo e da expressão de ferocidade, na qual lobo e ferocidade fundem-se em um tom selvagem e violento, embora ainda acuado como indica a expressão 'encolhida'.

$\mathrm{Na}$ sequência narrativa os dois homens se olham, parecem possuir a mesma face, mas não se falam, indiciando novamente o desconforto do narradorpersonagem ante o encontro. A mulher que o acompanha é quem fala com o homem, mas desagrada, já não é bem vinda segundo a voz do narrador-personagem que diz, de si para si: “... uma mulher interferindo no encontro entre dois homens." (ABREU, 2005:223). O uso do vocábulo 'interferindo' sugere que a mulher é desnecessária, até mesmo indesejada naquele momento. Por seu lado, o homem do apartamento procura tocar no narradorpersonagem, mas este sente que o toque vem em direção à sua disposição selvagem, violenta, à sua 'ferocidade de 
lobo' e teme pelo pior. Busca ver a vida, a paz, a virtude, a luz em seu eu interior, ou seja, um sentimento pacífico e receptivo, mas o lobo o domina, a violência selvagem o endurece e não consegue distinguir nada que remeta à virtude ao procurar ver em si mesmo, mas ainda assim tenta, conforme podemos observar no seguinte decurso narrativo:

Quem sabe no fundo do lago alguma gruta. Quem sabe no fundo da gruta alguma planta. Quem sabe no fundo da planta alguma flor. Quem sabe no fundo da flor alguma sede. Quem sabe no fundo da sede algum lago. (ABREU, 2005:224)

Olhando para seu eu interior, o lago, não consegue visualizar nenhum elemento de vida como sinalizam simbolicamente 'gruta', 'planta', 'flor' e 'sede'. Todos esses elementos trazem imanentes uma significação virtuosa, de manifestação da vida. Porém, o narradorpersonagem não sente uma alma interior de vida virtuosa, mas sim da selvageria do lobo.

Em seguida, após esse autoexame, afirma que o homem o tocava fisicamente, o encarava com "... as suas pupilas dentro das minhas. Um lago parado de águas apodrecidas e talvez mas apenas e antigamente guirlandas sobre o poço refletido num lago simplesmente limpo. Ou não." (ABREU, 2005:224). Essa passagem, pensamento do narrador-personagem, nos parece extremamente significativa, não apenas pela relação direta com o paratexto título, mas por revelar o interior das duas personagens, por meio da simbologia do lago, do poço, da água e da guirlanda.

Ele, o narrador-personagem, revela em suas pupilas um eu interior rígido, endurecido, estático e sem vida como se percebe na expressão 'lago parado de águas apodrecidas', portanto corrompidas e sem possibilidade de transformação, posto que a essência, a água, está podre. Por outro lado, no entanto, ressalva que em um passado remoto talvez tenha tido uma essência interior alegre, saudável - não podre - e receptiva, se considerarmos a guirlanda na acepção natalina de boas-vindas, ou ainda como "símbolos da vida eterna, da ressurreição e da alegria." (BIEDERMANN, 1999:183).

Evidentemente, a simbologia da guirlanda é plural, e como todo símbolo comporta duas facetas, podendo funcionar positivamente ou negativamente. Considerandose a estrutura narrativa, cremos na viabilidade de associála à vida, à alegria e à virtude, ou seja, um eu interior afável e receptivo.

Porém, essa possibilidade remota, como o afirma o narrador-personagem, é posta em dúvida pela alma estática e selvagem, violenta e feroz, pouco ou nada receptiva, ao encerrar com um 'ou não' que nega toda

a esperança contida na guirlanda. Por sua vez, o homem do apartamento apresenta 'um lago simplesmente limpo', sugerindo a pureza da alma interior, o caráter aberto, virtuoso e receptivo do mesmo, aspectos reiterados em vários momentos da narrativa e constituindo a dicotomia entre o narrador-personagem, de uma interioridade violenta, feroz, incompreensiva, reprimida, estática, e o homem do apartamento, com um espírito em vida, pacífico, compreensivo e amoroso. De forma sintética, "... tudo que em mim se anunciava rude nele se mostrava doce." (ABREU, 2005:224).

$\mathrm{Na}$ continuidade da narrativa, por meio de um diálogo interior, o narrador-personagem reafirma sua interioridade em elementos simbolicamente associados à violência, a selvageria de uma ferocidade de lobo. Formalmente, o segmento narrativo é deslocado como um bloco em separado do restante do texto, adquirindo uma similitude com a disposição formal dos versículos da bíblia:

\begin{abstract}
ainda que dentro de mim as águas apodreçam e se encham de lama e ventos ocasionais depositem peixes mortos pelas margens e todos os avisos se façam presentes nas asas das borboletas e nas folhas dos plátanos que devem estar perdendo as folhas lá bem ao sul e ainda que você me sacuda e diga que me ama e que precisa de mim: ainda assim não sentirei o cheiro podre das águas e meus pés não se sujarão na lama e meus olhos não verão as carcaças entreabertas em vermes nas margens ainda assim eu matarei as borboletas e cuspirei nas folhas amareladasdos plátanos e afastarei você com o gesto mais duro que conseguir e direi duramente que seu amor não me toca nem comove e que sua precisão de mim não passa de fome e que você me devoraria como eu devoraria você ah se ousássemos.
\end{abstract}

(ABREU, 2005:224-225)

Através desse diálogo consigo mesmo, corporificado em imagens simbólicas expressivas, o narradorpersonagem parece entrar em comunicação com o homem, pelo pensamento, e revelar enfaticamente sua disposição estática, violenta e não receptiva, ou seja, morta para um encontro que poderia colocá-lo em movimento de aceitação amorosa. A alusão ao apodrecimento das águas (princípio vital), à lama (corrompedora da pureza da água), aos peixes mortos (inanição) remete para uma consciência negativa de si. Ainda que veja os avisos nas borboletas (associadas à transformação) e que o homem diga que o 
ama, ele negará esse amor, submerso nas torpezas de sua interioridade que não sentirá os aspectos negativos, como os cadáveres cobertos por vermes ou a podridão da lama cobrindo as águas. O gesto definitivo de não aceitação do outro, da alteridade e de um sentimento de amor, mas sim de confirmação da violência do lobo, subido anteriormente do subterrâneo de si, configura-se em sua afirmação de matar as borboletas, de cuspir nas folhas dos plátanos e finaliza de forma dura e feroz ao afirmar que o amor do outro homem não o toca, nem o comove.

A transtextualidade com o texto bíblico, além da disposição formal, também se verifica no conteúdo, sobretudo em relação ao salmo 23:

\author{
O SENHOR é o meu pastor: \\ nada me faltará. \\ Ele me faz descansar \\ em pastos verdes \\ e me leva a águas tranquilas. \\ O SENHOR renova as minhas forças \\ e me guia por caminhos certos, \\ como ele mesmo prometeu.
}

Ainda que eu ande

por um vale escuro como a morte,

não terei medo de nada.

Pois tu, ó SENHOR Deus, estás comigo;

tu me proteges e me diriges.

Preparas um banquete para mim,

onde os meus inimigos me podem ver.

Tu me recebes

como convidado de honra

e enches o meu copo até derramar.

Certamente a tua bondade e o teu amor

ficarão comigo enquanto eu viver.

E na tua casa, ó SENHOR,

morarei todos os dias da minha vida.

(BÍBLIA SAGRADA, 2005:636-637)

A relação transtextual pode ser averiguada na disposição formal semelhante, no uso reiterado da expressão 'ainda que' no conto, estabelecendo um ritmo que se aproxima do versículo da bíblia 'ainda que eu ande' e no conteúdo veiculado de forma antagônica ao texto bíblico. No salmo 23, o narrador sente-se acolhido e protegido pela alteridade, e com uma disposição amorosa aceita o amor de Deus, em uma alegria agradecida e plena de vida. Na narrativa de Caio Fernando Abreu, o narradorpersonagem sente-se ameaçado pelo outro, pelo homem, e não aceita o amor, dominado pela violência selvagem de um eu interior simbolicamente representado na figura do lobo, e assim repele qualquer sentimento amoroso recíproco. Essa subversão do texto bíblico poderia ser considerada passível de proibição, segundo o Decreto no 20.493/1946, que estabelece a censura de mensagem potencialmente ofensiva à religião, e segundo Fagundes (1974) quanto à hostilização da religião. No entanto, somos cientes que a atribuição de tal entendimento do texto literário ao censor carece de maior fundamentação, sendo difícil atribuirmos a censura ao conto em função desse aspecto.

Enquanto o narrador-personagem imerge no pensamento descrito acima, o homem do apartamento parece compreendê-lo, pois o olha com tristeza. Percebendo esse olhar, uma vez mais a voz narrativa ratifica sua alma interior marcada pela dureza e violência, mas agora por meio de um diálogo exteriorizado, marcado graficamente, para o outro homem:

- Não farei um movimento para afastar os cadáveres que juncam as águas do lago não farei um movimento para conduzir o barco em direção ao sul pois sei que existem ventos e que os ventos sopram sei que se uma folha bater de leve no meu rosto eu a esmagarei feito mosca e sei que se houver cirandas pelas margens eu matarei as crianças sei do meu ser de faca sei do meu aprendizado de torpezas sei do que há no fundo desse lago e sei que você não o tocará porque a superfície não o revela... (ABREU, 2005:225)

Por meio do diálogo dirigido ao homem, enfatizase a ideia de um eu interior endurecido, estático, pois afirma que 'não farei um movimento', além de violento e não receptivo, conforme depreendemos ao afirmar que esmagará as folhas em seu rosto e matará as crianças pelas margens, símbolos de alegria e vida em oposição ao seu ser morto e sombrio, em suma, uma interioridade 'de faca'.

Nesse momento, o narrador-personagem afirma ter matado a mulher que o conduziu até o encontro, a qual, recordemos, o deixava incômodo desde o início da narrativa: "Eu tenho certeza que a matei naquele instante porque um pouco mais tarde ouvimos o sangue gotejar pelas escadas." (ABREU, 2005:225). Temos, assim, a revelação de um assassinato com um sentido visual impactante pela referência ao sangue escorrendo pelas escadas. Então se inicia o denominado 'depois' na narrativa.

Após o assassinato da mulher, tudo se torna turvo na memória e ele assassina também o homem do apartamento apunhalando-o, fincando-lhe agulhas e, por fim, sufocando-o, embora ressalve que o amava bastante e que desejava preveni-lo de suas ações violentas, em uma descrição um tanto melancólica:

Como o amava - e tanto - quis dizer-lhe que tivesse cuidado. E que se curvasse ao me ver baixando a mão até o cinto para retirar o punhal e depois e lentamente cravá-lo inúmeras vezes no seu peito múltiplo e que detivesse meu braço no momento exato em que eu começasse a fincar as agulhas no fundo verde dos 
olhos que eu não tive e distribuí-las pelo corpo inteiro em laborioso cuidado porque eu o amava - e muito - e suavemente distender os dois braços como quem faz um exercício e na ponta dos braços abrir as mãos que não foram magras como as dele e dedos nem tão longos como eu desejaria mas fortes o suficiente para armarem uma trama em torno de sua garganta e depois apertarem com destreza e encantamento até que seu rosto igual ao meu se contorça em ânsia e se congestione e descambe leve para o lado esquerdo e seus olhos contenham um espanto no intervalo entre o sempre e o nunca... (ABREU, 2005:226)

Uma possibilidade de leitura dessa aparente contradição, ou seja, amar e matar, pode ser aventada em uma especulação hipotética inscrita na seara de uma relação homoerótica. Os dados textuais, embora não sejam categóricos, sugerem tal situação: uma mulher leva um homem para encontrar outro; ela é vista como uma intrusa no momento do encontro e depois é assassinada; o homem do apartamento toca fisicamente e encara o narrador-personagem; este afirma que sentem amor um pelo outro; o homem do apartamento é receptivo, está pronto e livre para amar; por sua vez, o narradorpersonagem está endurecido em seu interior, haja vista seu 'aprendizado de torpezas', sugerindo, talvez, o aprendizado da moral e dos rigores do preconceito para com o homossexualismo, visto como imoral. Sente-se inerte, incapaz de romper com sua ferocidade, com sua disposição violenta, com seu eu interior petrificado e deixar-se amar livremente. Teríamos, então, o conflito interior em face das imposições repressivas da liberdade do indivíduo, ditadas pela moral convencional, que aqui atinge elevado grau de sedimentação no ser interior do narrador-personagem, o qual se torna incapaz de agir em desacordo com a normatividade em termos de relação amorosa. Assim, ao mesmo tempo em que ama o outro homem, sente-se dominado por caracteres negativos impostos pela moralidade social, instalando-se o conflito interior de onde emerge a violência, na figura do lobo e de sua ferocidade, e assassina, desejando evitar, o homem que ama. A moral tradicional, em seu peso coercitivo e limitador das liberdades individuais, também no preconceito em relação a uma opção homossexual, parte integrante do meio ideológico que cercava Caio Fernando Abreu, é refratada no conto, funcionando esteticamente na exposição do conflito interior do narrador-personagem e de sua explosão em uma violência não contida, simbolicamente representada no lobo que mata duas pessoas. Dado o simbolismo e o caráter intimista do conto, temos de reconhecer que a viabilidade dessa explicação somente se sustenta ao cruzarmos elementos textuais e contextuais, como a contracultura apresentada anteriormente e seus princípios de liberdade e individualidade, além do convencionado em termos de moral nas décadas de 1960 e 1970.

Ao fim da narrativa, ainda no 'depois', o narradorpersonagem abandona os dois cadáveres e sai do apartamento para a rua, de forma acelerada, sôfrega diante da violência brutal cometida, de sua incapacidade de romper com sua 'interioridade corrompida'. O ritmo acelerado, quase sem fôlego da ação se coaduna com o uso reiterado dos conetivos aditivos 'e', os quais permitem uma percepção desse ritmo acelerado, como se estivesse sufocando:

... abandonar os dois cadáveres e ultrapassar os labirintos metálicos para atingir o corredor de farpas engastadas e ver minha sombra única projetada nos ladrilhos escuros e comprimir o botão do elevador e abrir as grades e fechar as grades e descer e abrir as portas para ir além de um átrio iluminado pelo sol que não verei e recusar os toques e finalmente sair para a rua nova cheia de cores que não as minhas e sentir o lobo contrair-se voltando a ser inaparente e só então me deter. (ABREU, 2005:226)

As ações do narrador-personagem são maquinais, 'abrir', 'fechar', 'descer' e juntamente aos conetivos aditivos 'e' instalam uma sensação de rapidez vertiginosa, irrefletida, ou mesmo atordoada em razão dos dois assassinatos cometidos. Além disso, parece-nos que o narrador-personagem evidencia novamente a ideia de que o seu eu interior é marcado pela escuridão, pela selvageria do lobo, pois afirma que não verá o sol, que recusará os toques e verá cores, elementos associados à vida e à alegria, mas que não são as suas, posto que estas sejam escuras e sombrias. Finalmente, já na rua sente o lobo contraindo-se até desaparecer.

O conto, portanto, explora o conflito interior de um indivíduo incapaz de aceitar o amor de outro homem, apesar de amá-lo. Por meio do diálogo, em pensamento e com a personagem do apartamento, se autorrevela com uma linguagem simbólica que denota um aspecto negativo de sua interioridade como 'lago parado', 'escuro', 'águas podres', 'cadáveres', 'lama', 'lobo', 'ferocidade', 'faca' entre outros e estabelece uma relação com a 'alma verme' da epígrafe. Além disso, não consegue ver em si elementos positivos, ligados a uma significação de vida como 'planta', 'flor' e 'sede'. Dessa forma, constrói uma imagem de seu interior oprimido, sombrio e incapaz de aceitar o amor homoerótico, sufocado pelas normas morais e preconceitos sociais. O homem do apartamento, por outro lado, é construído como o oposto do narrador-personagem, com elementos positivos, em uma simbologia de pureza como 'água limpa', 'doce' e 'flor', ou seja, não endurecido ou não corrompido pelas imposições normativas da sociedade. 
Assim, a crítica social, em uma possibilidade de leitura, se expressa no poder degenerador da moral tradicional e do preconceito social sobre a interioridade do indivíduo, o qual, para não vivenciar uma relação homoerótica (apenas sugerida no texto) acaba por assassinar o homem que ama.

Evidentemente, a censura do conto pode ter levado em consideração essa sugestão de homoerotismo, embora não seja explícita, mas é-nos difícil afirmá-lo objetivamente. Desse modo, pensando na necessidade de uma objetivação da censura, e não em uma explicação subjetiva da mesma, parece-nos que a proibição efetuou-se em razão dos dois assassinatos, identificados literalmente no texto, e no fato de o assassino, além de sair impune ante o sistema judiciário, apresentar um comportamento violento e, sobremodo, feroz. Esses elementos, textualmente identificados pelo censor, seriam de fácil enquadramento na legislação sobre censura, como o Decreto n⿳⺈ 20.493/1946 e o Decreto-Lei no $1.077 / 1970$, por potencialmente ferir princípios éticos, induzir ao crime e gerar angústia por retratar a ferocidade. Segundo Fagundes (1974), a violência e a ferocidade deveriam ser assim entendidas pelo censor:

Até que se atinja a ferocidade de que fala a legislação, há inúmeros matizes de violência, de acordo com a maior ou menor intensidade dramática e clareza descritiva da cena, sem que se justifique o corte ou interdição. É preciso que o ato praticado pelo personagem toque as raias da crueldade, da perversidade, da desumanidade, enfim, assuma características de ação praticada por agente cuja índole o faz assemelhar-se a uma fera. (FAGUNDES, 1974:149)

$\mathrm{Na}$ narrativa, há dois assassinatos e um eu interior retratado como 'lobo' e dotado de 'ferocidade', ações e expressões que encontram proibição na legislação acerca de censura, sendo de relativa facilidade proibir a publicação do conto sob essas alegações, pautando-se, evidentemente, em um modo de pensar embasado na política de segurança nacional preconizadora de ações autoritárias e em contraste com o ideal de liberdade dos indivíduos.

Desse modo, a narrativa "Mas apenas e antigamente guirlandas sobre o poço" permite que percebamos a estetização axiológica de elementos extraestéticos constituintes do meio ideológico que circundava Caio Fernando Abreu, como o peso cerceador da liberdade de orientação sexual sobre os indivíduos e os valores da contracultura, e a censura executada pelo Instituto Estadual do Livro (IEL) revela um traço constituinte da formatação jurídico-política da Ditadura Civil-militar, ou seja, o autoritarismo. A narrativa de Caio Fernando Abreu apresenta-se, nessa perspectiva, como um contraponto simbólico ao traço autoritário, revestindo-se de significação axiológica valorizadora da liberdade individual e coletiva.

\section{Referências}

ABREU, Caio Fernando. O ovo apunhalado. Porto Alegre: Instituto Estadual do Livro/Globo, 1975.

ABREU, Caio Fernando. Caio 3D: o essencial da década de 1970. Rio de Janeiro: Agir, 2005.

ABREU, Caio Fernando. Ovelhas negras. Porto Alegre: L\&PM, 2011.

BAKHTIN, Mikhail. Marxismo e filosofia da linguagem: problemas fundamentais do método sociológico da linguagem. São Paulo: Hucitec, 2012.

BÍBLIA SAGRADA. São Paulo: Paulinas, 2005.

BIEDERMANN, Hans. Dicionário ilustrado de símbolos. São Paulo: Melhoramentos, 1999.

BITTENCOURT, Gilda Neves da Silva. O conto sul-riograndense: tradição e modernidade. Porto Alegre: Editora UFRGS, 1999.

BRASIL. Decreto no 20.493, de 24 de janeiro de 1946. Aprova o Regulamento do Serviço de Censura de Diversões Públicas do Departamento Federal de Segurança Pública. Disponível em: <http:/www2.camara.leg.br/legin/fed/decret/1940-1949/ decreto-20493-24-janeiro-1946-329043-publicacaooriginal-1pe.html>. Acesso em: 20 mar. 2013.

BRASIL. Decreto-lei no 1.077 , de 26 de janeiro de 1970. Dispõe sobre a execução do artigo $153, \S 8^{\circ}$, parte final, da Constituição da República Federativa do Brasil. Disponível em: <http:/www.planalto.gov.br/ccivil_03/Decreto-Lei/1965-1988/ Del1077.htm>. Acesso em: 05 fev. 2013.

CANDIDO, Antonio. Literatura e sociedade: estudos de teoria e história literária. Rio de Janeiro: Ouro sobre Azul, 2010.

CHEVALIER, Jean; GHEERBRANT, Alain. Dicionário de símbolos: mitos, sonhos, costumes, gestos, formas, figuras, cores, números. Rio de Janeiro: José Olympio, 2012.

DIP, Paula. Para sempre teu, Caio F. - cartas, memórias, conversas de Caio Fernando Abreu. Rio de Janeiro: Record, 2009.

FAGUNDES, Coriolano de Loyola Cabral. Censura e liberdade de expressão. São Paulo: Record, 1974.

GENETTE, Gérard. Palimpsestos: a literatura de segunda mão. Belo Horizonte: Edições Viva Voz, 2010.

GINZBURG, Jaime. Exílio, memória e história: notas sobre "Lixo e purpurina" e "Os sobreviventes" de Caio Fernando Abreu. Literatura e sociedade, São Paulo, n. 8, p. 37-45, 2005.

GOFFMAN, Ken; JOY, Dan. Contracultura através dos tempos: do mito de Prometeu à cultura digital. Rio de Janeiro: Ediouro, 2007.

MEDVIÉDEV, Pavel. O método formal nos estudos literários: introdução crítica a uma poética sociológica. São Paulo: Contexto, 2012.

PORTO, Luana Teixeira. Ovelhas negras: transgressão, violência e sofrimento. Literatura em debate, v. 7, n. 12, Frederico Westphalen, p. 247-262, 2013.

Recebido: 30 de outubro de 2014 Aprovado: 10 de abril de 2015 Contato: deivisjh@hotmail.com rosani.umbach@ufsm.br 